\title{
Torbangun Leaves (Coleus amboinicus Lour) Powder Capsules Supplementation Improve Lipid Profile and Blood Pressure in Men with Hypercholesterolemia
}

\author{
Niken Rizki Amalia', Muhammad Rizal Martua Damanik ${ }^{1 *}$, Ikeu Ekayanti ${ }^{1}$ \\ ${ }^{1}$ Department of Community Nutrition, Faculty of Human Ecology, Bogor Agricultural University, \\ Bogor 16680
}

\begin{abstract}
The aim of this study was to analyze the effect of torbangun leaves powder capsules supplementation on lipid profile and blood pressure in men with hypercholesterol. This study was a single blind randomized control trial design with 26 male subjects. The inclusion criterias for subject were adults (age 25-55 years), blood total cholesterol levels $\geq 200 \mathrm{mg} / \mathrm{dl}$, and signed the informed consent. Subjects were divided into two groups of one intervention (torbangun capsules) and one control (amylum) group. The intervention of $750 \mathrm{mg}$ /day torbangun powder for the intervention group and $300 \mathrm{mg}$ /day amylum for control group were administered for 28 days. The analysis of lipid profile results showed that the trygliseride, LDL, and HDL were not significantly affected by the torbangun intervention but it significantly decreased the total cholesterol level. The supplementation of torbangun capsules also decreased the sistolic blood pressure significantly, but not in diastolic pressure.
\end{abstract}

Keywords: antioxidant, cholesterol, lipid profile, sistolic blood pressure, torbangun leaves

\section{INTRODUCTION}

Health, education, and work productivity are important indicators for progress in development, advancement in those indicators are highly influenced by nutritional status. Regarding health and productivity, non-optimal nutritional status may cause health problems, especially non-infectious disease such as cardiovascular diseases (coronary heart disease, hypertension, and stroke), cancer, and diabetes. Better nutrition lead to better health through the maintenance of normal weight and increase immunity thus increasing work productivity, and protecting the body from chronic disease and early death (Syam et al. 2013).

There has been a big shift in disease burden from infectious diseases to non-infectious ones. More than 38 million people globally died from non-infectious disease. Cardiovascular disease (CVD) has become the main cause for death in various part of the world, including in Indonesia. Latest statistics in Indonesia pointed that CVD was accounted for as much as $37 \%$ from all death cases (WHO 2014). Death caused by cardiovascular disease, mainly coronary heart disease and stroke, is predicted to increase and reaching 23.3 million deaths in 2030 (Kemenkes RI 2014).
The common pathophysiology of cardiovascular disease such as coronary heart disease (CHD) begins with atherosclerosis plaque formation and hypertension. The cause of this atherosclerosis and hypertension are various, such as high levels of plasma total cholesterol, age, smoking habit, obesity, stress, diabetes mellitus, cholesterol, fat from food consumption, and dyslipidemia (Hu et al. 2001). Dyslipidemia, a condition where the metabolism of lipid is abnormal indicated by the increasing or decreasing of lipid fraction in plasma is one of the main risk for CHD. Thus blood lipid profile comprising of triglyceride, total cholesterol, LDL (Low Density Lipoprotein) cholesterol, and HDL (High Density Lipoprotein) cholesterol levels are often utilized as CHD risk parameters (Djohan 2004). Hence treating dyslipidemia will lower the risk for CHD.

Many studies on plants or natural resources' benefits for dyslipidemia and hypertension treatment have been reported in many countries (Lukacinova et al. 2008; Hsieh et al. 2010; Atef 2011; Batubara et al. 2012; Guo et al. 2014; Gengatharan et al. 2015; Herrera et al. 2016). In Indonesia, there are still many plants that have not been scientifically studied although people have utilized them for years as part of the local wis-

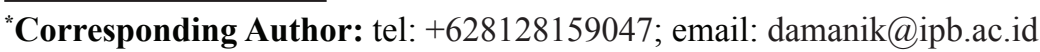


dom. One such plants is torbangun (Coleus amboinicus Lour).

Torbangun contains antioxidant, vitamin C, B1, B12, beta carotene, niacin, carvacrol, calcium, fatty acids, oxalate acid, and dietary fiber (Viswanathaswamy et al. 2011; Nadernejad et al. 2012). Helmizar (2010) stated that higher consumption of antioxidant significantly showed better levels of triglyceride, LDL, HDL, and total cholesterol. In addition, consumption of vegetables and fruits which are rich in dietary fiber, vitamin, mineral, and antioxidant may prevent degenerative diseases, mainly caused by blood pressure and cholesterol (Depkes RI 2007). Antioxidant plays a role in controlling the oxidative stress as biostimulator to increase the function of pancreas $\beta$-cells and insulin sensitivity, so that it prevents metabolic disorder syndrome. Torbangun's antioxidant which are flavonoid, terpenoid, and saponin as well as its ascorbic acid content obstructs the oxidative stress resulting in the hypoglycemic and hypocholesterolemia effects (Shenoy et al. 2012).

Batubara et al. (2012) mentioned that mineral contents in torbangun leaves are calcium, potassium, magnesium, iron, $\alpha$-tocopherol, $\beta$-carotene, essential oil, phenol, thymol, carvacrol, phorscoline, isopropyl ocresol, sinerol, flavonoids, and glycoside. Biological activities from those compounds as antioxidant, diuretic, analgesic, anti-cancer, anti-tumor, anti-vertigo, immunostimulator, anti-inflammation, anti-infertility, hypocholesterolemic agent, hypotensive agent, and other benefits still requires further study (Roshan et al. 2010). A research conducted by Viswanathaswamy et al. (2011) reported that torbangun leaves extract has shown an anti-hyperglycemia and anti-hyperlipidemia activities by ameliorating carbohydrate and fat metabolism disorder, and by improving the concentration of intracellular calcium in mice. Suryowati et al. (2015) reported that the ethanol extract of torbangun leaves has the potential to be a biostimulator for improvement in blood lipid profile in mice with type 2 of diabetes.

Andriani et al. (2012) highlighted that torbangun leaves capsule significantly preserved the cholesterol total in normal condition of healthy subjects. Alvianti's research (2015) also proved that subjects who consume torbangun capsule and fishes in 28 days significantly had lower blood pressure compared to ones consuming fishes without torbangun capsule.

Many researches on the potential and contents of torbangun have been conducted, but research to obtain information on its benefit to lipid profile is still limited to animal test. Previous research on human only observed its effect on healthy subjects and have not encompassed a comprehensive lipid profile change, so this underlay the purpose of this research to obtain information about torbangun effects on subjects with hypercholesterolemia. The purposes of this research were 1) to understand the differences of subject's characteristics that can act as confounding factors for the research; 2) to analyze the effect of torbangun powder capsule supplementation towards blood lipid profile (cholesterol total, triglyceride, LDL, and HDL) of adult male subjects with hypercholesterolemia; 3 ) to analyze the effect of torbangun powder capsule supplementation towards blood pressure (systolic and diastolic) of adult male subjects with hypercholesterolemia.

\section{METHODS}

\section{Design, locaion, and time}

The study design was experimental. This research was conducted from January to June 2017. Torbangun powder was made in Southeast Asian Food and Agricultural Science and Technology (SEAFAST) Center IPB laboratory. The capsule making was conducted in Liza Herbal Indonesia. Next, intervention capsule distribution was conducted in rectorate building in IPB. The analysis of blood lipid profile was conducted in Labkesda (Regional's health laboratory) Bogor.

\section{Sampling}

Sample populations in this research were non-academic staff of Bogor Agricultural University. They were chosen purposively by applying the inclusion and exclusion criteria. Inclusion criteria of research's subject were adult man aged 25-55 years old; cholesterol levels of $\geq 200 \mathrm{mg} / \mathrm{dl}$; healthy; never drink alcohol, any supplements, traditional or any herbal medicines; never consume any drugs that lowering cholesterol level routinely, willing to fill the informed consent and willing to participate in the research until the end. The exclusion criteria were having serious illness, had to be hospitalized or consuming certain medicines routinely, and participating in another researches.

This research has obtained the ethical approval from Medical Ethic Commission Number of 585/UN2.F1/ETIK/2017, Faculty of Medicine, University of Indonesia. 
Subjects were divided into two groups, one was intervention group that given torbangun capsule and control group given amylum capsule. The subjects for this study were 13 people for each group, so that the total subjects were 26 people. The sample size determination was calculated using the Lameshow et al. (1997) formula.

$\mathrm{n}=\frac{2(Z \alpha+Z \beta) \sigma^{2}}{\delta^{2}}=\frac{2(1.96+1.28) 42.8^{2}}{55^{2}}=12.71 \approx 13$ people

The usage of various levels and expected decrease in lipid profile levels referred to Avianti (2015).

\section{Data collection}

The data collected in this research were subjects' characteristics (age, weight, height, and nutrition status based on BMI), life style (smoking and exercise habits), lipid profile (total cholesterol, triglyceride, HDL, LDL), and blood pressure (systolic and diastolic). The data on age and life style were collected through interview and questionnaire. Weight, height, and blood pressure data were collected by measuring it directly. Blood pressure and lipid profile were measured twice. before intervention and after intervention. Lipid profile was analyzed from blood taken from subjects' vein, previously obligated to fast at least for 10 hours. The blood taking process was done by health personnel from Labkesda (Regional Health Laboratory) of Bogor.

Subjects' weight was measured using digital scales (Omron), height was measured using microtoise. BMI was calculated using the $\mathrm{BW}$ $(\mathrm{kg}) / \mathrm{BH}^{2}\left(\mathrm{~m}^{2}\right)$ formulation. The systolic and dyastolic blood pressure were measured using digital bloods pressure monitor, meanwhile lipid profile (total cholesterol, triglyceride, HDL, and LDL) were analyzed with spectrophotometry method.

\section{Procedures}

Production of torbangun powder capsule.

The torbangun powder used for the intervention was produced at the beginning of this research. The method was started by sorting fresh and light green torbangun leaves and soft stems to be washed and blanched. Then the leaves were all milled with miller and dried by using drum dryer. Next, the leaves were all mashed by using disk mill and sieved ,sized 60 mesh strainer.
Before being encapsulated, analysis was conducted on torbangun powder including moisture content, nutrient content of macro substances as well as some vitamins and minerals. A hundred gram of torbangun powder contained $9.8 \%$ water, $14.1 \%$ ash, $25.7 \mathrm{~g}$ protein, $7.4 \mathrm{~g}$ fat, $41.9 \mathrm{~g}$ carbohydrate, $72.5 \mathrm{mg}$ iron, $3911.9 \mathrm{mg}$ magnesium, $472.6 \mathrm{mg}$ calcium, and $67.7 \mathrm{mg}$ vitamin $\mathrm{C}$. The production method and nutrition content were in accordance with research conducted by Andriani et al. (2012).

The finely-ground torbangun powder was then put into 0 (zero) sized capsule with dosage of $250 \mathrm{mg}$ per capsule. The dosage used in this research was $750 \mathrm{mg}$ torbangun powder each day (three capsules). The control group received 300 $\mathrm{mg}$ amylum in capsules, as if it is consumed in small amount, it will not give any effect.

Intervention. Before intervention, subjects were screening and those who has total cholesterol $\geq 200 \mathrm{mg} / \mathrm{dl}$ were chosen to be intervened. The screening was conducted by health analyst on the peripheral blood sample using Easy Touch UGC device. Intervention was given for 28 days, started a day after the blood sample for pre-intervention lipid profile was taken.

The intervention group took torbangun capsule as many as three capsules per day and control group had one amylum capsule per day. The supplement was packed in labelled bottles and given to subjects three times per day, at the same time. Intervention of subjects compliance were controlled using questionnaires. During the intervention period, researcher was assisted by a doctor to anticipate any further complaints occurred from the subjects.

\section{Data analysis}

Data were processed using Microsoft Excel 2013 and analysed SPSS 16.0 version. Sample characteristic data was analyzed descriptively for mean, median, standard deviation, minimum value, and maximum value. Observed variables were measured before and after intervention on each subject according to the group. The Paired t-test was used to see the difference of value on each group before and after intervention. The Independent t-test was conducted for analyzing the different test on each variable between intervention and control groups. The ANCOVA test was used to determine the effect of torbangun intervention by controlling covariate variables. 
Amalia et al.

\section{RESULTS AND DISCUSSION}

\section{Subject characteristics}

Most of subjects were around 46-55 years old. Average weight of all subjects before intervention was $72.5 \pm 9.1 \mathrm{~kg}$. Nutrition status assessment based on Body Mass Index (BMI) showed that most of subjects were classified as obese with BMI of $26.9 \pm 2.8 \mathrm{~kg} / \mathrm{m}^{2}$ in average. Obesity may increase the risk of developing insulin resistance and dyslipidemia (Choi et al. 2002). Individual's blood pressure condition is determined by the systolic and diastolic blood pressure. The average of systolic and diastolic blood pressure in control group before the intervention was higher that the intervention group, but the independent t-test did not show the significant difference between the two groups ( $p>0.05)$. Most of subjects' condition were pre-hypertension $(42.31 \%$ ) (Table 1).

The cholesterol levels before intervention in both groups were not significantly different $(p>0.05)$ and all subjects were in hypercholesterolemia with average cholesterol levels was 231.1 $\mathrm{mg} / \mathrm{dl}$. Fifteen subjects were having high levels of triglyceride before intervention, meanwhile the rest of them were normal $(178.0 \pm 83.3 \mathrm{mg} /$ dl) for all subjects. Most subjects (73.08\%) had low le-vels of HDL and high levels of LDL (25 people, $95.15 \%$ ) before intervention.

Subjects involved in this research should be in homogenous condition to reduce research

Tabel 1. The distribution of subjects based on intervention

\begin{tabular}{|c|c|c|c|c|}
\hline Variabel & Intervention & Control & Total & $\mathrm{p}$ \\
\hline Age (year) & $46.9 \pm 7.2$ & $51.5 \pm 3.9$ & $49.19 \pm 6.1$ & $0.060^{2)}$ \\
\hline $25-35$ n $(\%)$ & $1(7.69)$ & $0(0.00)$ & $1(3.85)$ & \\
\hline $36-45$ n $(\%)$ & $3(23.08)$ & $2(15.38)$ & $5(19.2)$ & \\
\hline $46-55$ n $(\%)$ & $9(69.23)$ & $11(84.62)$ & $20(76.92)$ & \\
\hline Body Weight (kg) & $70.2 \pm 8.1$ & $74.0 \pm 10.1$ & $72.5 \pm 9.1$ & $0.306^{2)}$ \\
\hline BMI $\left(\mathrm{kg} / \mathrm{m}^{2}\right)$ & $25.8 \pm 2.6$ & $27.2 \pm 2.9$ & $26.9 \pm 2.8$ & $0.212^{1)}$ \\
\hline Underweight n (\%) & $0(0.00)$ & $0(0.00)$ & $0(0.00)$ & \\
\hline Normal n $(\%)$ & $4(31.77)$ & $3(23.08)$ & $7(26.92)$ & \\
\hline Overweight n (\%) & $4(31.77)$ & $2(15.38)$ & $6(26.08)$ & \\
\hline Obesity n (\%) & $5(38.46)$ & $8(61.54)$ & $13(50.00)$ & \\
\hline Sistolic Blood Pressure $(\mathrm{mmHg})$ & $137.8 \pm 20.6$ & $142.0 \pm 14.3$ & $139.9 \pm 17.5$ & $0.557^{1)}$ \\
\hline Diastolic Blood Pressure ( $\mathrm{mmHg}$ ) & $82.2 \pm 11.4$ & $82.8 \pm 9.1$ & $82.5 \pm 10.1$ & $0.895^{1)}$ \\
\hline Normal n (\%) & $2(15.38)$ & $0(0.00)$ & $2(7.69)$ & \\
\hline Pre Hipertentionn $(\%)$ & $6(46.15)$ & $5(38.46)$ & $11(42.31)$ & \\
\hline Stadium 1 hipertention $\mathrm{n}(\%)$ & $2(15.38)$ & $7(53.85)$ & $9(34.62)$ & \\
\hline Stadium 2 hipertention $n(\%)$ & $3(23.08)$ & $1(7.69)$ & $4(15.38)$ & \\
\hline Cholesterol (mg/dl) & $229.8 \pm 15.8$ & $232.5 \pm 17.4$ & $231.1 \pm 16.3$ & $0.683^{1)}$ \\
\hline Normal n $(\%)$ & $0(00.00)$ & $0(00.00)$ & $0(100.00)$ & \\
\hline High n $(\%)$ & $13(100.00)$ & $13(100.00)$ & $26(100.00)$ & \\
\hline Triglyseride (mg/dl) & $183.4 \pm 95.6$ & $172.5 \pm 72.5$ & $178.0 \pm 83.3$ & $0.747^{1)}$ \\
\hline Normal n $(\%)$ & $6(46.15)$ & $5(38.46)$ & $11(42.31)$ & \\
\hline High n $(\%)$ & $7(53.85)$ & $8(61.54)$ & $15(57.69)$ & \\
\hline HDL (mg/dl) & $49.4 \pm 10.1$ & $41.8 \pm 8.7$ & $45.6 \pm 10.0$ & $0.051^{1)}$ \\
\hline Low n $(\%)$ & $12(92.31)$ & $7(53.85)$ & $19(73.08)$ & \\
\hline Normal n $(\%)$ & $1(7.69)$ & $6(46.15)$ & $7(26.92)$ & \\
\hline LDL (mg/dl) & $132.4 \pm 21.7$ & $167.3 \pm 45.5$ & $149.8 \pm 39.2$ & $0.023 * 1)$ \\
\hline Normal n $(\%)$ & $1(7.69)$ & $0(0.00)$ & $1(3.85)$ & \\
\hline High n $(\%)$ & $12(92.31)$ & $13(100.00)$ & $25(96.15)$ & \\
\hline
\end{tabular}

${ }^{1)}$ Independent T-test. ${ }^{2}$ Mann-Whitneybetweencontrol and intervention group; *significantly in $\mathrm{p}<0.05$ 
bias. The analysis result showed that subjects at each groups had no significant differences $(p>0.05)$ at all characteristics before intervention, except for early LDL levels $(\mathrm{p}<0.05)$ in which the control group had higher LDL level.

The ANCOVA analysis was conducted to determine the effect of covariate variables that might influence the outcome of changes in lipid profile and blood pressure. Covariate variables thought to be confounding factors for intervention effect was LDL cholesterol levels before intervention as there was significant difference bet-ween control and intervention groups. The analysis result showed that LDL levels before intervention significantly influenced the LDL levels after intervention $(p<0.05)$ and had no significant effect to blood pressure or other lipid profile variables. The negative value of regression coefficient of estimates on LDL levels changes showed the reversed relationship between LDL levels before intervention and LDL levels decreasing after intervention.

\section{The effect of torbangun powder capsule on lipid profile}

The result of lipid profile analysis showed that after treatment (Table 2), the cholesterol levels of intervention group significantly change $(p<0.05)$. This result was in line with Viswanathaswamy et al. (2011) and Suryowati et al. (2015) statementthat torbangun contained antioxidant component which can lower cholesterol levels, but the research results showed differences with no significant change in triglyceride, LDL, and HDL levels ( $p>0.05)$. This difference was suspected because research of Viswanathaswamy et al. (2011) and Suryowati et al. (2015) used mice, not human.

After the research, cholesterol levels of control group were increased. Lack of antioxidant consumption can lead to increase free radicals which interfere the insulin receptors then affect the metabolism of glucose and fat, that cause increasing glucose in the blood and increased li- polysis in fat tissue (Chang et al. 2013). Research from Lipid Research Clinics Coronary Primary Prevention Trial (LRCCPPT) in the US pointed the relationship between cholesterol lowering with risk reduction of coronary heart disease, where every $1 \%$ decrease in blood cholesterol would lower the risk of coronary heart disease as much as $2 \%$ (Fodor et al. 2000).

There was a decrease in triglyceride and LDL levels after taking the torbangun capsule intervention for 28 days, although the value was not significant. Meanwhile the different test result showed that there was no significant change in cholesterol total, triglyceride, LDL and HDL levels.

There were decrease in HDL level in both groups, but in the intervention group, the decreasing of HDL level is lower than control group. Base on the ANOVA test, the mean value of LDL level change adjusted with the covariat variables showed that there was a decrease in LDL level in the intervention group, while for control group, it was an increase. Non-significant lipid profile improvement especially for trigly-ceride, LDL, and HDL probably caused by high consumption of carbohydrate and fat (as a common shift in Indonesian diet from traditional to an easy to prep meals) in which the diet of the participants in this study was not controlled. Based on data, the average carbohydrate ade-quacy of subjects was classified into over-category $(\geq 120 \%$ of individual needs). Erejuwa et al. (2011) stated that high consumption of carbohydrate and fat caused insulin resistance, which will lead to hypertriglyceridemia and low HDL. In addition. non-significant changes were also thought to be caused by the less intervention time. Research conducted by Baba et al. (2007) regarding plant intervention with antioxidant contents especially polyphenol took longer time (around twelve weeks) was proven the reduction of total cholesterol, LDL, triglyceride, and increasing HDL in human.

Tabel 2 .The change of lipid profiles before and after treatment

\begin{tabular}{|c|c|c|c|c|c|c|c|c|c|}
\hline \multirow{2}{*}{$\begin{array}{l}\text { Variabel } \\
(\mathrm{mg} / \mathrm{dl})\end{array}$} & \multicolumn{4}{|c|}{ Intervention group } & \multicolumn{4}{|c|}{ Control group } & \multirow{2}{*}{$\mathrm{p}^{3}$} \\
\hline & Before & After & Change & $\mathrm{p}^{1}$ & Before & After & Change & $\mathrm{p}^{2}$ & \\
\hline Cholesterol & $229.8 \pm 95.6$ & $216.8 \pm 21.1$ & $-13.0 \pm 19.8$ & $0.036^{*}$ & $232.5 \pm 17.4$ & $233.9 \pm 29.9$ & $1.5 \pm 21.9$ & 0.814 & 0.090 \\
\hline Triglyseride & $183.4 \pm 95.6$ & $170.0 \pm 82.8$ & $-13.4 \pm 50.55$ & 0.353 & $172.5 \pm 72.5$ & $164.2 \pm 60.0$ & $-8.3 \pm 55.8$ & 0.601 & 0.810 \\
\hline LDL & $49.4 \pm 10.1$ & $49.2 \pm 11.4$ & $-0.2 \pm 7.6$ & 0.943 & $41.8 \pm 8.7$ & $40.8 \pm 7.2$ & $-1.0 \pm 4.4$ & 0.432 & 0.732 \\
\hline HDL & $132.4 \pm 21.7$ & $129.1 \pm 19.1$ & $-3.3 \pm 15.2$ & 0.446 & $167.3 \pm 45.5$ & $160.3 \pm 31.7$ & $-7.0 \pm 33.4$ & 0.464 & 0.709 \\
\hline
\end{tabular}

1)Paired t-test between before and after treatment in intervention group; ${ }^{2)}$ Paired t-test between before and after treatment in control group; ${ }^{3)}$ Independent t-testbetween the change of intervention and control group; *significantly in $\mathrm{p}<0.05$ 
Result showed that torbangun leaf has a potential as anti-hypercholesterolemia (Yadav et al. 2008). It could be expected that the anti-hypercholesterolemia effects occurred through inhibition process of HMG-CoA reductase enzyme in cholesterol biosynthesis and cholesterol absorption in small intestine (Sharma et al. 2003). The inhibition of cholesterol production would inhibit the forming of LDL and increase HDL efficiency in blood vessel. HDL as LDL transporter from tissue to liver is excreted by bile. HDL inhibits the oxidation of LDL by metal ionic transition and 12-lipooxygenase in which prevents the forming of lipid hydroperoxide. The decreasing of HDL levels in the intervention group was thought to be a result of the HDL's activity as an antioxidant in transporting cholesterol, it is supported by the tendency of decreased levels of LDL in the blood (Assmann \& Gotto 2004).

\section{The effect of torbangun powder capsule sup- plementationon to blood pressure}

Systolic blood pressure analysis result showed that there was a significant difference in torbangun capsule consumption during 28 days $(p<0.05)$ before and after treatment in intervention group (Table 3 ). There was a decrease of $-8.5 \pm 13.3 \mathrm{mmHg}$ in average. Meanwhile in control group, although they experienced the decreasing of systolic blood pressure, it was not significant $(\mathrm{p}>0.05)$. The diastolic blood pressure in the intervention group were increasing, meanwhile in control group decreased, but there was no significant difference between both groups before and after intervention.

Blood pressure is the pressure inflicted on the artery wall, where peak pressure occurs when the ventricle contracts and is called systolic pressure. Diastolic pressure is the lowest pressure when blood filling into the heart before being pumped throughout the body (the pressure that occurs when the heart rests) (Smeltzer \& Bare 2001).
Based on the data above, it could be seen that torbangun capsule may decrease systolic blood pressure significantly in men with hypercholesterolemia. This was in line with a research conducted by Alvianti (2015) that consuming torbangun with fish may decrease blood pressure significantly compared to consume only fish. Moreover, this result was in line with Ardalan \& Rafieian-Kopaei (2014) who stating that the consumption of antioxidant from suplement was significantly lowered systolic blood pressure, but not significant for diastolic blood pressure. This could cause by changes in the fresh ingredients into supplement causing antioxidant chains to be incompletely available.

Systolic blood pressure decreasing mechanism was thought to be caused by lipid profile improvement by decreasing cholesterol, triglyceride, and LDL. So that thickening process of artery wall might be halted. Torbangun contains flavonoid such as quercetin acting as antioxidant which is able to inhibit insulin resistance by repairing pancreatic $\beta$ cell to prevent hyperglycemia and hyperlipidemia that could cause metabolic syndrome (Suryowati et al. 2015; Chang et al. 2013). The thickening of artery wall caused by accumulation of lipid plaque might constrict diameter of blood vessel and clog the bloodstream, it cause our body need a higher pressure to flow the blood throughout the body. The continuousity of high blood pressure that caused by accumulation of lipid plaque might omit the elasticity of blood vessel, therefore it would be no longer able to regulate blood pressure. Thus, heart attack or stroke may happened (Erejuwa et al. 2011).

Antioxidant in some vegetables or fruits such as polyphenol also play roles in decreasing superoxide dismutase and glutathione peroxidase's activities which may lead to oxidative stress, a trigger for hypertension (Baradaran et al. 2014). Feryadi et al. (2014) mentioned that respondents with high levels of cholesterol had a 2.09 times higher risk of hypertension than those with normal levels.

Tabel 3.The change of blood pressure between before and after treatment

\begin{tabular}{|c|c|c|c|c|c|c|c|c|c|}
\hline \multirow{2}{*}{$\begin{array}{l}\text { Variabel } \\
(\mathrm{mmHg})\end{array}$} & \multicolumn{4}{|c|}{ Intervention group } & \multicolumn{4}{|c|}{ Control group } & \multirow{2}{*}{$\mathrm{p}^{3}$} \\
\hline & Before & After & Change & $\mathrm{p}^{1}$ & Before & After & Change & $\mathrm{p}^{2}$ & \\
\hline $\begin{array}{l}\text { Sistolic blood } \\
\text { pressure }\end{array}$ & $137.8 \pm 20.6$ & $129.3 \pm 17.1$ & $-8.5 \pm 13.3$ & $0.039^{*}$ & $142.0 \pm 14.3$ & $137.5 \pm 13.9$ & $-4.5 \pm 9.5$ & 0.111 & 0.387 \\
\hline $\begin{array}{l}\text { Diastolic blood } \\
\text { pressure }\end{array}$ & $82.2 \pm 11.4$ & $83.2 \pm 10.8$ & $0.9 \pm 9.5$ & 0.732 & $82.8 \pm 9.1$ & $82.4 \pm 7.8$ & $-0.4 \pm 5.1$ & 0.789 & 0.667 \\
\hline
\end{tabular}

${ }^{1}$ Paired t-test between before and after treatment in intervention group; ${ }^{2)}$ Paired t-test between before and after treatment in control group; ${ }^{3)}$ Independent t-test between the change of intervention and control group; *significantly in $\mathrm{p}<0.05$ 


\section{CONCLUSION}

Total cholesterol significantly decreased after consumption of torbangun capsule as much as $-11.8 \mathrm{mg} / \mathrm{dl}$ after being adjusted with covariate variable $(\mathrm{p}<0.05)$. Meanwhile, there was no significant difference in lipid profile of control group ( $p>0.05)$. Triglyceride, LDL, and HDL le-vels of intervention group did not change significantly $(\mathrm{p}>0.05)$. However, the torbangun consumption showed a tendency to decrease triglyceride and LDL levels, meanwhile for the control group they experienced an increase of LDL after intervention. Torbangun capsule supplementation also significantly decreased the systolic blood pressure $(\mathrm{p}<0.05)$ as much as $-7.7 \mathrm{mmHg}$.

Torbangun consumption could be used as antioxidant alternative source to help reducing the cholesterol level and systolic blood pressure, especially in subjects with hypercholesterolemia. Analysis of antioxidant contents and torbangun leaves potential utilization for health requires in further study. Duration of intervention, determination of dosage used, and addition of control group are noteworthy for next study to be considered. In addition, the measurement of biomarker change should be conducted every 7 days or once in a week.

\section{ACKNOWLEDGEMENT}

Authors would like to thank to all subjects of the study and Human and Resource Development Division of Bogor Agricultural University that allowed us to use the data of subjects and did the study.

\section{REFERENCES}

Alvianti S. 2015. Pengaruh suplementasi kapsul serbuk daun torbangun (Coleus amboinicuslour) dan konsumsi ikan secara rutin terhadap tekanan darah dan total kolesterol [tesis]. Bogor: Institut Pertanian Bogor.

Andriani E, Damanik R, Ekayanti I. 2012. Correlation of torbangun leaves (Coleus amboinicus Lour.) powder capsules suplementation on blood pressure and cholesterol. J Tek Ind Boga 3(1):14-22.

Ardalan M, Rafieian-Kopaei M. 2014. Antioxidant supplementation in hypertension. J Renal Inj Prev 3(2):39-40.

Assmann G, Gotto AM. 2004. HDL cholesterol and protective factors in atherosclerosis. Circulation 109:III-8-III-14. doi: 10.1161/01.CIR.0000131512.50667.46.
Atef EAE. 2011. Quercetin protective action on oxidative stress, sorbitol, insulin resistance and $\beta$-cells function in experimental diabetic rats. Int J Pharm Stud Res 2(2):11-18.

Baba S, Naomi O, Yoji K, Midori N, Akiko Y, Toshimi K, Kumiko F, Yuko M, Kazuo K. 2007. Continuous intake of polyphenolic compounds containing cocoa powder reduces LDL oxidative susceptibility and has beneficial effects on plasma HDLcholesterol concentrations in humans. Am J Clin Nutr 85:709-717.

Baradaran A, Nasri H, Rafieian-Kopaei m. 2014. Oxidative stress and hypertension: Possibility of hypertension therapy with antioxidants. J Res Med Sci 19(4):358-367.

Batubara I, Kotsuka S, Yamauchi, Kuspradini H, Mitsunaga T, Darusman LK. 2012. Produksi TNF- $\alpha$ aktivitas penghambatan, fenolik, flavonoid, tanin, dan isi tanaman obat Indonesia yang dipilih. Research Journal of Medicinal Plant 6:406-415.

Chang CLT, Lin Y, Arlene PB, Chen YC, Chiu SC, Yang WC. 2013. Herbal therapies for type 2 diabetes mellitus: chemistry, biology, and potential application of selected plants and compounds. Evid Based Complement Alternat Med 13(3):1-33. doi:10.1155/2013/378657.

Choi JW, Pai SH, Kim SK. 2002. Associations between total body fat and serum lipid concentrations in obese human adolescents. Annals of Clinical \& Laboratory Science 32(3):271-278.

[Depkes RI] Departemen Kesehatan Republik Indonesia. 2007. Pedoman Pengendalian Penyakit Jantung dan Pembuluh Darah. Direktorat Jenderal Pengendalian Penyakitdan Penyehatan Lingkungan. Jakarta: Depkes RI.

Djohan TB. 2004. Penyakit Jantung Koroner dan Hipertensi. Medan: Universitas Sumatera Utara.

Erejuwa OO, Sulaiman SA, Wahab MSA, Sirajudeen KN, Salleh MSM, Gurtu S. 2011. Differential responses to blood pressure and oxidative stress in streptozotocin-induced diabetic wistar-kyoto rats and spontaneously hypertensive rats: effects of antioxidant (honey) treatment. Int J Mol Sci 12(3):1888-1907.

Feryadi R, Sulastri D, Kadri H. 2014. Hubungan kadar profil lipid dengan kejadian hipertensi pada masyarakat etnik Minangkabau di kota Padang tahun 2012. J Kesehatan Andalas 3(2):206-211. 
Fodor JG, Frohlich JJ, Genest JG, McPherson PR. 2000. Recommendations forthe management and treatment of dyslipidemia. CAMJ 162(10): 1441-1447.

Gengatharan A, Dykes GA, Choo WS. 2015. Betalains: Natural plant pigments with potential application in functional foods. Food Sci Technol Int 64:645-649.

Guo M, Liu Y, Gao Y, Shi D. 2014. Chinese herbal medicine on dyslipidemia: progress and perspective. ECAM 2014 (ID 163036). doi:10.1155/2014/163036.

Helmizar, Jalal F, Liputo I. 2010. Antioksidandalam masakan minang dan potensi protektif terhadap risiko penyakit kardiovaskular. JAKA 4(1):13-20.

Herrera M, Rodriguez O, Torregrosa L, Vasquez M, Blanco E, Calderon L. 2016. Traditional use of plants as antihypertensive in Jipijapa, Manab \& Iacute; Comparison with the literature. In Proceedings of the MOL2NET. International Conference on Multidisciplinary Sciences. 25 December 2016-25 January 2017; Sciforum Electronic Conference Series 2. doi:10.3390/ mol2net-02-03890.

Hsieh PC, Huang GJ, Ho YL, Lin YH, Huang SS. 2010. Activities of antioxidants. $\alpha$-glukosidase inhibitors and aldose reductase inhibitors of the aqueous extracts of four Flemingia species in Taiwan. Botanical Studies 51:293-302.

Hu FB, Manson JE, Willet WC. 2001. Types of dietary fat and risk of coronary heart disease. J Am Coll Nutr 20(1):5-19.

[Kemenkes RI] Kementrian Kesehatan Republik Indonesia. 2014. Situasi Kesehatan Jantung. Jakarta: Pusat Data dan Informasi Kesehatan Jantung Kemenkes. Jakarta: Kemenkes.

Lukacinova A, Mojzis J, Benacka R, Keller J, Maguth T, Kurila P, Vasko L, RaczO, Nistiar F. 2008. Preventive effects of flavonoids on Alloxan-induced diabetes mellitus in rats. J Acta Vet Brno 77(2):175-182.

Nadernejad N, Ahmadimoghadam A, Hosseinifard J, Pourseyedi S. 2012. Phenylalanin ammonialyase activity, total phenolic and flavonoid content in flowers, leaves, hulls, and kernels of three pistachio (Pistaciavera L.) cultivars. American-Eurasian J Agric Environ Sci 12(6):807-814.

Roshan DP, Naveen KM, Manjul PS, Anita S, Naheed WS, Gulzar A, Sudarshan KS.
2010. Antioxidant potential of leaves of Plectranthus amboinicus (Lour) Spreng. Der Pharmacia Lettre 2(4):240-245.

Smeltzer CS. Bare GB. 2001. Buku Ajar Keperawatan Medikal Bedah edisi 8. Jakarta: EGC.

Sharma SB, Nasir A, Prabhu KM, Murthy PS, Dev G. 2003. Hypoglycaemic and hypolipidemic effect of ethanolic extract of seeds of eugenia jambolana in alloxan induced diabetic rabbits. J Ethnopharmacol 85(2):201-206.

Shenoy S, Kumar H, Thashma, Nayak V, Prabhu K, Pai P. 2012. Hepatoprotective activity of Plectranthus amboinicus against Paracetamol induced hepatotoxicity in rats. Int J of Pharm Sci 1(2):32-38.

Suryowati T, Rimbawan, Damanik R, Bintang M, Handharyani E. 2015. Antihyperlipidemic activity of Torbangun extract (Coleusamboinicuslour) on diabetic rats induced by streptozotocin. IOSR J Pharm Biol Sci 5(1):50-64.

Suryowati T, Rimbawan, Damanik R, Bintang M, Handharyani E. 2015. Identifikasi komponen kimia dan aktivitas antioksidan dalam tanaman Torbangun (Coleus amboinicus Lour). J Gizi Pangan 10(3):217-224.

Syam FM, Lubis Z, Siregar MA. 2013. Gambaran asupan zat gizi, status gizi, dan produktivitas kerja pada pekerja pabrik kelapa sawit Bagerpang Estate PT. PP. LONSUM 2013. GKRE 2(5):1-9.

Viswanathaswamy AHM, Koti BC, Gore A, Thippeswamy AHM, Kulkarni RV. 2011. Antihyperglycemic and antihyperlipidemi activity of plactranthusamboinicus on normal and alloxanindiced diabetic rats. Indian J Pharm Sci 73(2):139-145.

[WHO] World Health Organization. 2014. Global Status Report on Noncommunicable Disease 2014. available on http://apps.who.int/iris/bitstre $\mathrm{am} / 10665 / 148114 / 1 / 9789241564854$ eng. pdf?ua $=1$ (accessed $4^{\text {th }}$ of November 2016).

Yadav JP, Sushila S, Kalia AN, Dangi AS. 2008. Hypoglycemic and hypolipidemic activity of ethanolic extract of Salvadora oleoides in normal and alloxan induced diabetic rats. Indian J Pharm Sci 40:23-27. 